\title{
Microplastics Exposure Routes and Toxicity Studies to Ecosystems: An Overview
}

\author{
Christian Ebere Enyoh ${ }^{1}$ D, Leila Shafea ${ }^{2}$, Andrew Wirnkor Verla ${ }^{1}$, Evelyn Ngozi Verla ${ }^{3}$, Wang Qingyue ${ }^{4}$, Tanzin Chowdhury ${ }^{4}$, \\ Marcel Paredes ${ }^{5}$ \\ 'Group Research in Analytical Chemistry, Environment and Climate Change (GRACE\&CC), Department of Chemistry, Imo State University (IMSU), PMB \\ 2000 Owerri, Imo State, Nigeria; ${ }^{2}$ Department of Soil Science, Universität Kassel, Kassel, Germany; ${ }^{3}$ Department of Environmental Technology, School of \\ Environmental Science, Federal University of Technology, Owerri, P.M.B.1526, Imo State, Nigeria; ${ }^{4}$ Graduate School of Science and Engineering, Saitama \\ University, Saitama, Japan; ${ }^{5}$ Department of Civil Engineering, National University of Chimborazo, Riobamba, Ecuador
}

\begin{abstract}
Microplastics (MPs) are now ubiquitous in global ecosystem, therefore all biota is at risk of exposure and potential toxicity. In this study, we presented an overview of information based on literature concerning exposure to MPs and the toxicity of such exposure. Currently, four major routes of exposure have been identified including entanglement, contact, ingestion and inhalation. Humans maybe the most exposed organism because they are at the peak of the food chain. Toxicology effect to marine and freshwater organisms are classified based on exposure dosage as either high (mortality, decreased reproductive output, organ damage) or low (changes in behavior with time). On plants, reports have shown that MPs exposure can affect negatively the growth and depending on exposure concentration and types of MPs and oxidative activities. However, effects on plants maybe short-term and transient. Although, toxicity studies regarding human are still ongoing as per reports, plants and animals are still scantly studied. Animal toxicity studies have widely used $D$. magna as model specie. MPs pollution may have a knock-on effect on trophic structure and functioning of ecosystems by affecting the base of the food chain. We concluded by identifying the gap in knowledge and give recommendations for future research.
\end{abstract}

Keywords: Air, Soil, Water, Food, Human health, Toxicity, Exposure, Micropollutants

\section{INTRODUCTION}

Plastic products with tremendous consumption are ubiquitous in our daily lives and the annual production of plastics is drastically increasing [1]. It is now expected to reach 33 billion tonnes by 2050 [2] with plastic waste in the environment projected to reach 67.8 million metric tons by the same year [3]. The pollution of plastic cum microplastics (MPs) from degradation in the environment is currently a hot issue attracting the global attention of many scientists, governmental and non-governmental organization and the public media [3-7]. Although few studies have investigated the chemical behavior and toxicity of MPs in the natural environment, studies focusing on its toxicity in tandem with toxic chemicals to ecosystems are scarce $[1,4,8]$. There are many toxicology reports that MPs are harmful to ecosystems. Terrestrial organisms such as

Received: January 18, 2020 Accepted: March 4, 2020

Corresponding author: Christian Ebere Enyoh

Imo State University, PMB 2000, Owerri, Nigeria

E-mail: cenyoh@gmail.com

This article is available from: https://eaht.org/ earthworms, soil collembolans, and other animals, as well as plants have been affected by MPs [1,4,9-13]. Also, aquatic organisms such fish, sandhoppers, sea turtle, crustacean and mussel have also been affected by MPs [14-15]. In addition, humans are exposed to MPs via trophic transfer or by direct ingestion, contact and inhalation and plausible effects include lung inflammation and genotoxicity may occur $[1,3,16,17]$. Aside from the innate toxicity of MPs, they can carry different toxic chemicals such as heavy metals and organic pollutant by adsorption process, and double the effect of such pollutants $[1,8,18]$.

Succinctly, plastic products are made up of mixtures of polymers, fillers, and multiple additives to improve its usability. Also, there are other chemicals including unreacted monomers, starting substances and non-intentionally added substances (NIAS; impurities, side or breakdown products) that are also present in plastic. However, most of these chemicals are not covalently bound to the polymer, so they can be released at all stages of the plastics' life cycle via migration to liquids or solids or via volatilization [1]. Therefore, plastic materials are an important source of human exposure to chemicals. 
The well-known examples are the plastic monomer bisphenol A (BPA) and phthalate esters used as plasticizers [19]. More route of attachment of environmental chemicals to plastics is through formed biofilm on the microplastic surface and hydrophobic adsorption (for adsorption and desorption mechanism see ref. [1]).

According to the recent studies around toxicities of plastics and their chemical releases, more analyses of the dangers of MP pollution to terrestrial biodiversity are required because the abundance, composition and physicochemical surface properties of particulate material follow typical patterns in terrestrial and continental environments [20, 21]. Recently Verla et al. presented a comprehensive review of the interaction between MP and toxic chemicals as well as the implications of such interaction to ecosystems [1]. In their review, they reported that twelve metals - aluminum (Al), arsenic (As), cadmium $(\mathrm{Cd})$, chromium $(\mathrm{Cr})$, cobalt $(\mathrm{Co})$, copper $(\mathrm{Cu})$, iron $(\mathrm{Fe})$, manganese $(\mathrm{Mn})$, nickel $(\mathrm{Ni})$, lead $(\mathrm{Pb})$, titanium (Ti), and zinc $(\mathrm{Zn})$; one halogen - bromine $(\mathrm{Br})$; and fifteen groups of organic pollutants - polycyclic aromatic hydrocarbons (PAHs), Polychlorinated biphenyls (PCBs), dichloro-diphenyl-trichloroethane (DDTs), hexachlorocyclohexane (HCHs), chlordane, mirex, hexachlorobenzene, hopanes, polybrominated diphenyl ether (PBDEs), perfluorinated compound/acid (PFC/ PFA), aliphatic hydrocarbons, BPA, nonylphenols (NPs) and octylphenols (OPs) have generally been quantified from different locations globally up till now. These chemicals are ubiquitous just as MPs and are abundant in areas of high anthropogenic activities [1]. Further, they can adversely affect human health with potential carcinogenic, teratogenic and mutagenic effects [22]. The study aimed at presenting a summary of studies conducted on exposure and toxicities of MPs to man and environment. Understanding the route of exposure to MPs may help preventing lethal effects they may pose to biota.

\section{EXPOSURE ROUTE TO MICROPLASTICS}

MPs are ubiquitous in the environment since they have been found in all components of the ecosystems [4]. Therefore, biota interact each other either from the soil, water or air. Sizes, density, abundance, shape, and color of MPs control its bioavailability [1] and therefore its toxicological effect. In the last five years, research have focused on the transfer and the effects of MPs through the food chain. Diverse species are currently being investigated to find out more susceptible species to MPs exposure [23]. Cunningham and Sigwart presented a meta-analysis of experimental exposure studies (number of studies $=128$ ) on marine and freshwater species to MPs [24]. Exposure impact of MPs was classified as either high (decreased reproductive output, damage to organ and mortality) when dosage is greater than $100 \mathrm{MPs} / \mathrm{L}$ for water and greater $100 \mathrm{MPs} / \mathrm{kg}$ for sediment and low (transient behavioral changes such as increased respiration, reduced feeding, and reduced energy) when dosage is $\leq 100 \mathrm{MPs} / \mathrm{L}$ for water and $\leq$ $100 \mathrm{MPs} / \mathrm{kg}$ for sediment. The threshold for a cut-off between the two classes was selected based on the highest recorded environmental surface water concentrations [25]. Although concentrations of MPs can vary with time, the threshold of 100 $\mathrm{MPs} / \mathrm{L}$ is intended to represent the highest values of MPs reported at a given time [24]. Therefore, different cut-off size will

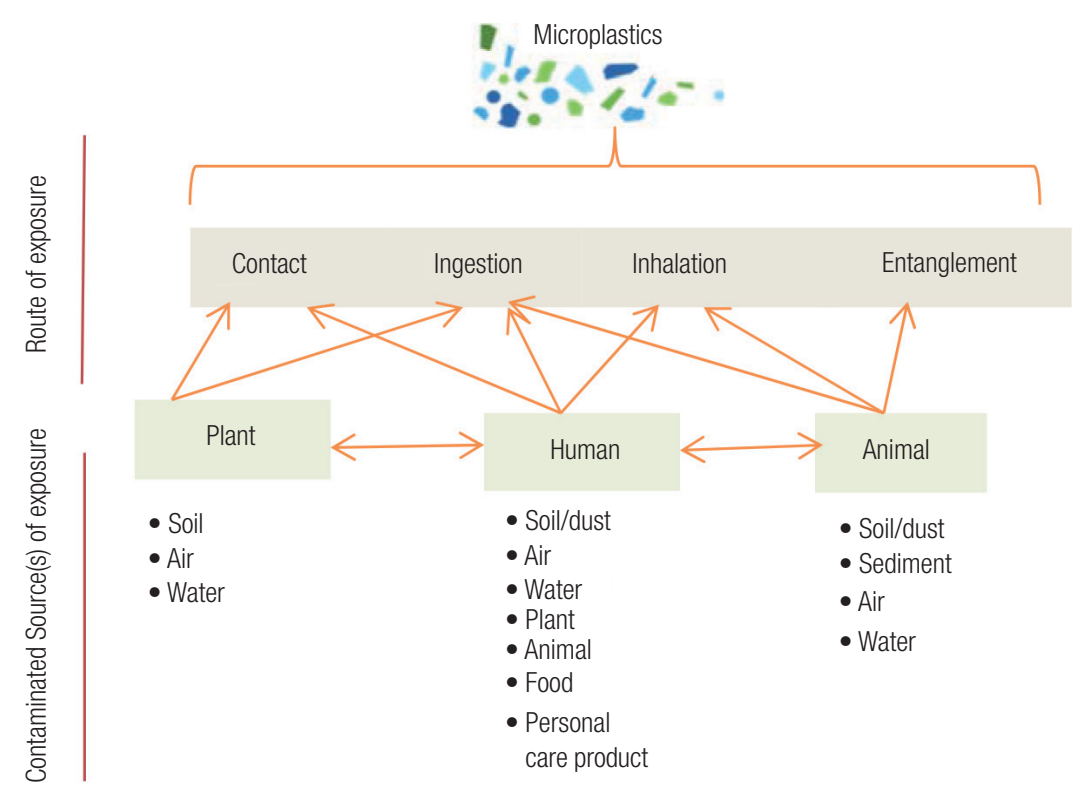

Figure 1. Summary of exposure route to environmental microplastics (MPs) 
lead to different values, since number concentration of MPs is size-dependent. However, many species either by selective targeting of plastic items, or accidental ingestion by filtration or predation are exposed directly to MPs [26]. Based on current information, all categories of exposure fall under the four major routes to MPs: entanglement, contact, ingestion and inhalation (Figure 1). Entanglement and contact are similar, but this study regarded them as different based on the mode of exposure. Contact involves attachment and/or penetration through skin pores while entanglement is defined when MPs remain attached/packed on the surface/body of the organism, which can cause the organism to sink if in water.

\section{Plant}

Plants are exposed to MPs through contact (from MPs fallout or through contaminated water or irrigation water) and ingestion by uptake through the rhizosphere in the plastic-soil matrix. Contact exposure was reported for aquatic plant e.g. Duckweed (lemma minor) and moss plant (Sphagnum palustre $\mathrm{L}$ ). MPs made of polyethylene (PE) are adhering to whole $L$. minor colonies by exposing to $50,000 \mathrm{MPs} / \mathrm{mL}$ of size dimension of 10-45 $\mu \mathrm{m}$ [27]. Capozzi et. al. [79] also made similar observation for polystyrene (PS) on S. palustre L in freshwater. Overall, prolong exposure to the treatment showed increasing adherence to MPs in water by aquatic plant $[27,79]$, thus they can be used for monitoring MPs contamination of freshwater environments.

Recent studies have also suggested that plants which are exposed to MPs in the soil matrix have the potential to uptake them [4]. Studies have shown nanoplastics $(<100 \mathrm{~nm})$ and MPs $(0.2 \mu \mathrm{m})$ can uptake by a plant $[28,29,80,82]$. This is hypothetically possible because small-sized MPs can bypass plant cell wall and membrane barriers or block cell pores $[4,18,82]$.

\section{Animal}

The exposure route of animals, including marine and soil organisms, to MPs is by entanglement and ingestion $[1,15]$. One of the major reasons why some marine organisms get entangled or ingest MPs is due to the formation of biofilm on the microplastic surface [1]. Biofilm forming processes on virgin microplastic particles begin within seconds of the first contact with ambient water $[1,30]$.

The number of marine species reported to have interacted with plastic debris has increased over time with current counts over 1,000, while about 800 of these have shown interaction with MPs [31]. Previous reports showed that by ingestion 220 species were contaminated and through entanglement 580 species were contaminated and these organisms include ma- rine mammals, fish, invertebrates and fish-eating birds $[1,32,33]$. However, soil animals such as nematodes, collembolan, oligochaeta (e.g. earthworms) and isopods are also known to interact within different ways and ingest soil plastic debris [1].

Land or terrestrial animals are mainly herbivorous, e.g. goat, cow, etc., and they may be exposed indirectly by consuming MP-contaminated plant and/or directly from consuming contaminated animal feed or water. Carnivores, e.g. lion, tiger, etc., may then be exposed through food-chain process or trophic transfer by consuming or feeding on herbivores tissues and bio-system. The food chain exposure processes are also often exhibited in the aquatic ecosystem, for example, whale or sharks feeding on smaller marine animals may have ingested MPs or amphipod Gammarus duebeni eating PE laden L. minor [27]. Generally, data on the presence of MPs in freshwater macroinvertebrates are scarce, as most studies have focused on fish and birds [34].

\section{Human}

The routes of exposure of humans to MPs are diverse. The summary and mechanism of exposure are presented in Figure 1. The ingestion may be by oral route which involves consumption of contaminated water, food products (honey and beverages), through use of personal care products (toothpaste, face wash, scrubs, soap; also dermal route), marine product (food chain), plant (food chain), contact (dermal) from soil, water or fallout of airborne MPs, from particulate fallout from air during open meal and inhalation.

Humans may also be directly exposed to MPs through the actual ingestion of these particles from drinking water, honey, beers and table salt [35-38]. MPs have been found in drinking water sources but in low concentrations $[40,78]$. Analysis of beer samples in Germany reported about 2 to 79 fibers/L and from 12 to 109 fragments/L [36]. Recently, Karami et al. analyzed different salt brands $(n=17)$ from 8 countries for MPlike particles and observed that the salts were predominantly contaminated by fragments of polypropylene (PP) and PE [37]. Through salt consumption, it was estimated that at most 37 particles per individual were ingested [1]. Although, these routes of exposure to MPs through consumption of salts pose no/negligible health risks as concluded by researchers [38,39]. Another route of direct ingestion of MPs is from atmospheric fallout of indoor airborne MPs during open meals [3]. Cantarino et al. demonstrated this exposure route in their study and extrapolated that humans may inject MPs which ranged from 13,731 to 68,415 particles per year from this scenario $[4,41]$.

MPs can also be ingested indirectly through personal care 
products such as toothpaste, face wash, scrubs and soap $[42,43]$. There are reports of MPs present in diverse personal care products. Results from a recent study showed that $50 \%$ of the face wash products and $67 \%$ of the facial scrubs studied mainly contained microbeads [44]. These microbeads can cause skin aging and dark spots on the skin by letting in bacteria through the tiny rips formed. Kaur explained that tiny rips in the skin may occur from exposing the skin to microbeads in personal care products [44]. Microbeads can also injure the cornea when it gets stuck in under the eyelid from face washing. There are many reports of the presence of MPs in toothpaste products [45]. MPs in toothpaste can lead to gingivitis and bleeding with prolonged exposure when trapped between gum [44].

The food chain exposure process is based on human consuming MPs contaminated aquatic organisms, animals or plants, which in turn may have consumed the plastic through MP loaded water or the feeding from other organisms. There are many studies which reported the presence MPs in various organisms from the lowest levels of food chain such as zooplanktonic organisms to the highest levels in both invertebrates (Crustacea, mollusks) and vertebrates (fish) [1,15,4648]. Güven et al. studying the Mediterranean coast (Turkey) for MPs in fishes, reported a total of 1,822 and 1,337 MP particles were recovered from stomachs and intestines respectively [49]. Furthermore, it was also reported MPs reached $92.3 \%$ of the total number of plastic items (meso-/micro- plastics) in fishes collected from coastal and freshwater in China [37]. MPs have also been recently found in the livers of fish fed plastic particles [39]. It was estimated that a top European shellfish consumer will consume 11,000 plastic particles annually by the aforementioned route [1]. Another aspect of food chain exposure is by consuming contaminated plants. Previous reports have demonstrated the potentiality of plant bioaccumulating MPs and from extrapolations, they may consume about 80 g daily [4].

Dermal exposure may occur when humans interact with water or soil contaminated with MPs or from contact with particulate MPs. Contact (dermal) exposure will be through skin pores penetration. Exposure by this means is based on individual susceptibility as human skin pores vary by individual. Very small synthetic fibers $(<25 \mu \mathrm{m})$ can penetrate skin pores which is as small as $40-80 \mu \mathrm{m}$, but they will bypassed the striatum corneum [4,51-53].

Humans may also be exposed to MPs through inhalation. This is only possible when the MPs become airborne $[4,6]$. Few studies have reported the presence of MPs in indoor and outdoor air [4]. For MPs to be inhalable, it must have a size that can allow it reaches the respiratory system and not conform to the criteria of fiber provided by World Health Organization (WHO), i.e. must have a length more than $5 \mu \mathrm{m}$, with a diameter less than $3 \mu \mathrm{m}$, and a length-to-diameter ratio more than 3:1 [54]. Recently, Vianello et al. observed from their simulated experiment using a breathing thermal manikin (BTM) that over $24 \mathrm{~h}$, humans may inhale airborne MPs up to 272 particles from inhaling indoor air [55]. Although using BTM cannot truly replicate the complexity of the branching airways of the human lung, the findings from the study still expose the high potential exposure route through inhalation [5].

\section{TOXICITY STUDIES ON MICROPLASTICS}

Chemicals can be adsorbed to MPs surfaces and may pose threat biota post-ingestion. The precise mechanisms by which MPs adsorb toxic chemicals in the environment is yet to be understood fully, although the plausible mechanism involves: hydrophobic adsorption, biofilm and plastic additives [1]. MPs, therefore, serve as a carrier for toxic chemicals such as heavy metals and organic pollutants in the environmental matrix. Toxicity studies of MPs to marine and terrestrial animals have been well conducted whereas plants are scarcely studied and recently started gaining increasing attention while no reports yet concerning humans.

\section{Plants}

The effects of MPs on soil-plant and water-plant systems have started gaining increasing attention recently. MPs in soil matrix can affect the soil properties including soil aggregation, bulk density and water holding capacity and may also affects water properties such as total dissolved and suspended solids, electrical conductivity, $\mathrm{pH}$ and dissolved oxygen [3,5-6,56]. Plants are usually exposed to MPs from the soil matrix and the effect or toxicity they have maybe dependent on plant, type, shape, size and concentration of MPs [1,4]. Studies conducted so far have focused on vegetative and reproductive growth as well as chlorophyll contents of plants. These studies are summarized in Table 1. In soil-plant systems, most studies have adopted an approach of comparing the outcome of single and combined exposure. Reports so far have shown that MPs exposure can affect negatively, depending on exposure concentration and types, on the growth and varying effects on oxidative activities of plants. However, effects maybe short-term and transient.

Animals

Although using animal as biomarker are commonly used for 
Table 1. Summary of toxicological studies of microplastics (MPs) exposure on plants

\begin{tabular}{|c|c|c|c|c|c|c|c|}
\hline $\begin{array}{l}\text { Matrix } \\
\text { studied }\end{array}$ & MPs type & Treatment & Plant studied & $\begin{array}{c}\text { Plant } \\
\text { part }\end{array}$ & Result & Conclusion & References \\
\hline \multirow[t]{6}{*}{ Soil } & \multirow[t]{2}{*}{ Bio and LDPE } & \multirow[t]{2}{*}{$\begin{array}{l}1 \% \text { with and } \\
\text { without } \\
\text { earthworm }\end{array}$} & \multirow[t]{2}{*}{$\begin{array}{l}\text { wheat } \\
\text { (Triticum aestivum) }\end{array}$} & $\begin{array}{l}\text { Above- } \\
\text { ground }\end{array}$ & $\begin{array}{l}\text { Bio-affected above ground biomass } \\
\text { negatively reducing plant height, } \\
\text { number of tillers, fruits and causing } \\
\text { thinner stem during the growth pro- } \\
\text { cess while LDPE showed no clear ef- } \\
\text { fect in comparison with control. }\end{array}$ & \multirow[t]{2}{*}{$\begin{array}{l}\text { Earthworm had a positive effect on } \\
\text { the wheat growth and chiefly allevi- } \\
\text { ated the impairments made by plas- } \\
\text { tic residues increasing total biomass } \\
\text { by } 26.2 \% \text { after } 4 \text { months. However, } \\
\text { both Bio and LDPE significantly af- } \\
\text { fected the total biomass. }\end{array}$} & \multirow[t]{2}{*}{ [13] } \\
\hline & & & & $\begin{array}{l}\text { Below- } \\
\text { ground }\end{array}$ & $\begin{array}{l}\text { Significant decrease in below-ground } \\
\text { biomass }\end{array}$ & & \\
\hline & \multirow[t]{2}{*}{$\begin{array}{l}\text { Synthetic fibre, } \\
\text { Bio-PLA and HDPE }\end{array}$} & \multirow[t]{2}{*}{$\begin{array}{l}0.001 \% \mathrm{w} / \mathrm{w} \text {, } \\
0.1 \% \mathrm{w} / \mathrm{w} \text { and } \\
0.1 \% \mathrm{w} / \mathrm{w} \\
\text { respectively. }\end{array}$} & \multirow[t]{2}{*}{$\begin{array}{r}\text { perennial ryegrass } \\
\text { (Lolium perenne) }\end{array}$} & $\begin{array}{l}\text { Above- } \\
\text { ground }\end{array}$ & $\begin{array}{l}\text { Shoot height was reduced especially } \\
\text { for synthetic fibre and Bio-PLA. In- } \\
\text { creased chlorophyll a and b contents } \\
\text { compared to control. }\end{array}$ & \multirow[t]{2}{*}{$\begin{array}{l}\text { The study provided evidence that MPS } \\
\text { manufactured of HDPE. PLA, and } \\
\text { synthetic fibers can affect the devel- } \\
\text { opment of L. perenne health }\end{array}$} & \multirow[t]{2}{*}{ [56] } \\
\hline & & & & $\begin{array}{l}\text { Below- } \\
\text { ground }\end{array}$ & $\begin{array}{l}\text { Seed germination was reduced espe- } \\
\text { cially for synthetic fibre and Bio-PLA. } \\
\text { Increased root biomass compared to } \\
\text { control except bio-PLA }\end{array}$ & & \\
\hline & LDPE, PP and PS & $\begin{array}{l}0.5 \% \text { w/w } \\
(\text { LDPE, PP, PS } \\
\text { respectively), } \\
1 \% \text { w/w } \\
\text { (for LDPE+PP, } \\
\text { LDPE+PS, PP+PS } \\
\text { respectively) and } \\
1.5 \% \text { w/w } \\
(\text { LDPE+PP+PS) }\end{array}$ & $\begin{array}{l}\text { Juvenile Lime Tree } \\
\text { (Citrus aurantium) }\end{array}$ & $\begin{array}{l}\text { Above } \\
\text { ground }\end{array}$ & $\begin{array}{l}\text { Showed more negative effects com- } \\
\text { pared to control by reducing height, } \\
\text { number of branches, leaf number and } \\
\text { area. Highest negative effect shown } \\
\text { by LDPE while least by LDPE+PP+PS }\end{array}$ & $\begin{array}{l}\text { C. aurantium generally showed high } \\
\text { tolerance (>70\%) to the different } \\
\text { treatment groups. Despite the ob- } \\
\text { served toxicity symptoms as the de- } \\
\text { crease in total plant biomass, there } \\
\text { was no unfavorable impact on the } \\
\text { relative growth rate (RGR) of the } \\
\text { tree. }\end{array}$ & [57] \\
\hline & $\begin{array}{l}\text { Green fluorescent } \\
\text { Microspheres }\end{array}$ & $\begin{array}{l}103 \text { to } 107 \\
\text { Particles/mL }\end{array}$ & $\begin{array}{l}\text { vascular plant } \\
\text { (Lepidium sati- } \\
\text { vum) }\end{array}$ & $\begin{array}{l}\text { Below- } \\
\text { ground }\end{array}$ & $\begin{array}{l}\text { Reduced germination after } 8 \text { hours of } \\
\text { exposure with no significant differ- } \\
\text { ences after } 24 \text { hours from the control }\end{array}$ & $\begin{array}{l}\text { Increasing exposure concentration, } \\
\text { size and time reduces germinating } \\
\text { rate and chlorophyll contents. }\end{array}$ & [80] \\
\hline Sediment & PS & $10 \%$ dry weight & $\begin{array}{l}\text { M. spicatum } \\
\text { Elodea sp. }\end{array}$ & $\begin{array}{l}\text { Above- } \\
\text { ground }\end{array}$ & $\begin{array}{l}\text { Shoot length reduced with increasing } \\
\text { concentration }\end{array}$ & $\begin{array}{l}\text { All effects occurred at higher than en- } \\
\text { vironmentally realistic concentra- } \\
\text { tions, suggesting no immediate im- } \\
\text { plications for ecological risks. }\end{array}$ & [81] \\
\hline \multirow[t]{5}{*}{ Water } & \multirow[t]{2}{*}{ PE Microbeads } & \multirow[t]{2}{*}{$\begin{array}{l}0,10,50, \\
\text { and } 100 \mathrm{mg} / \mathrm{L}\end{array}$} & \multirow[t]{2}{*}{$\begin{array}{l}\text { duckweed } \\
\text { (L. minor) }\end{array}$} & Root & $\begin{array}{l}\text { Significant decrease in root length with } \\
\text { increasing concentration }\end{array}$ & \multirow[t]{2}{*}{$\begin{array}{l}\text { Overall, results showed that specific } \\
\text { leaf growth rate and content of pho- } \\
\text { tosynthetic pigments in duckweed } \\
\text { leaves are not negatively affected by } \\
\text { polyethylene microbeads. However, } \\
\text { investigated particles significantly } \\
\text { affected the root growth }\end{array}$} & \multirow[t]{2}{*}{ [58] } \\
\hline & & & & Leaves & $\begin{array}{l}\text { After seven days treatment caused } \\
\text { less than } 10 \% \text { inhibition in compari- } \\
\text { son to control }(<8 \%) \text { with no signifi- } \\
\text { cant effect. Furthermore, photosyn- } \\
\text { thetic pigment concentration (chloro- } \\
\text { phyll a and b) was not significantly } \\
\text { affected compared to controls }\end{array}$ & & \\
\hline & \multirow[t]{2}{*}{ PE } & \multirow[t]{2}{*}{ 50,000 MPs/mL } & \multirow[t]{2}{*}{$\begin{array}{l}\text { duckweed } \\
\text { (L. minor) }\end{array}$} & Root & $\begin{array}{l}\text { Root length increased with time from } \\
24 \text { to } 168 \text { hours with no significant } \\
\text { differences from the control }\end{array}$ & \multirow[t]{2}{*}{$\begin{array}{l}\text { Over seven days PE MPs did not af- } \\
\text { fect photosynthetic efficiency and } \\
\text { plant growth. However, 30-day } \\
\text { chronic exposure showed some } \\
\text { negative effect on root and leaves. }\end{array}$} & \multirow[t]{2}{*}{ [27] } \\
\hline & & & & Leaves & $\begin{array}{l}\text { Photosynthetic pigment concentration } \\
\text { (chlorophyll a and b) was not signifi- } \\
\text { cantly affected compared to controls }\end{array}$ & & \\
\hline & PS-MPs & $\begin{array}{l}5 \mu \mathrm{m} \text { with } 10, \\
50 \text { and } 100 \mathrm{mg} / \mathrm{L}\end{array}$ & Vicia faba & $\begin{array}{l}\text { Whole } \\
\text { plant }\end{array}$ & $\begin{array}{l}\text { Reduced growth with varying effect on } \\
\text { enzyme activities such as catalase } \\
\text { (CAT) (decreased significantly), super- } \\
\text { oxide dismutase (SOD) and peroxidase } \\
\text { (POD) (both increased significantly). }\end{array}$ & $\begin{array}{l}\text { Showed mild genotoxic effects on the } \\
\text { plant and most probably block cell } \\
\text { connections or cell wall pores for } \\
\text { transport of nutrients. }\end{array}$ & [82] \\
\hline
\end{tabular}

\footnotetext{
*Bio: Biodegradable; PLA: polylactic acid, HDPE: high density polyethylene, PP: polypropylene, PS: polystyrene, LDPE: low density polyethylene.
} 
neuro- and genotoxicity, this review focused more on the studies that related toxicity to sorption of toxic chemical by MPs [59-64]. Many animals collected from both marine and terrestrial ecosystems have shown to ingest MPs $[1,15,18]$. Therefore, studying the role of MPs in the toxicity of chemical contaminants cannot be underemphasized. A review of toxicity studies on animals by MPs-toxic chemical interaction has been conducted recently [65]. Most studies have used Daphnia magna (a small planktonic crustacean belonging to the subclass Phyllopoda; adult length is usually $1.5-5.0 \mathrm{~mm}$ ) as a model specie.

Outcome comparison of single and combined effects of MPs approach has been commonly adopted across studies. For example, Rehse et al. using D. magna reported that the half maximal effective concentration $\left(\mathrm{EC}_{50}\right)$ for the immobilization of BPA did not differ significantly from when the organism is treated with both BPA and polyamides (PA) [66]. Furthermore, Horton et al. reported that the immobilization and toxicity of pesticide (dimethoate and deltamethrin) by $D$. magna was not affected when polystyrene (PS) was introduced [67]. Using the same organism, similar observation was also made for the immobilization of phenanthrene alone and with irregular PE MPs [68]. For predatory performance of Pomatoschistus microps, Fonte et al. reported an increase in $\mathrm{EC}_{50}$ due to combined exposure effects to cefalexin and PE spheres [69]. Davarpanah and Guilhermino showed that the $\mathrm{EC}_{10}$ (maximal effective concentration at $10 \%$ inhibition), $\mathrm{EC}_{20}$ (maximal effective concentration at $20 \%$ inhibition) and $\mathrm{EC}_{50}$ of $\mathrm{Cu}$ alone on algae (Tetraselmis chuii) growth inhibition did not differ from the obtained ECx when PE MPs were added with $\mathrm{Cu}$ [70]. Therefore, it could be said that PA, PS and PE MPs did not affect the toxicity of the cefalexin, BPA, dimethoate and deltamethrin, phenanthrene and $\mathrm{Cu}$ to aquatic organisms [65].

For other chemicals, such as glyphosate, 17a-ethinylestradiol and $\mathrm{Ni}$, toxicity and MPs type (e.g. PVC), reports have suggested that MP-presence may decrease or increase contaminant toxicity depending on treatment methods. Zhang et al. observed an antagonistic effect on the growth of the algae (Microcystis aeruginosa) due to the interaction of glyphosate and PS-NH2 [64]. A gene expression study reported that the bioavailability of phenanthrene and 17a-ethinylestradiol to zebrafish in the presence of MPs decreased significantly due to sorption of these chemicals to PVC [71]. Additive effect such as increasing bioaccumulation of phenanthrene was observed for small plastic particles $(50 \mathrm{~nm})$ in combination with phenanthrene on D. magna [72]. PS and PS-COOH in water showed antagonistic and synergistic effects on Ni toxicity to D. magna [73]. The toxicity of the latter may have been enhanced by the presence of carboxylic acid functional group, which enabled easy bonding with water molecules. Mateos-Cárdenas et. al., [27], recently observed that at 24 and $48 \mathrm{~h}$ exposure of G. duebeni to PE MPs via trophic transfer from contaminated L. minor showed negligible effect on the amphipod mortality or mobility. Furthermore, juveniles of a planktivorous fish (Acanthochromis polyacanthus) showed great tolerance to acute and chronic exposure to polyethylene terephtalate (PET) with no significant effect on growth, body condition or behavior [74].

For terrestrial organisms, soil invertebrates, such as nematodes, collembolan, oligochaeta (e.g. earthworms) and isopods have been studied $[1,9,56]$. The toxicological effect of MPs on soil organisms have been extensively discussed and reviewed $[1,9]$. Toxicity is controlled by exposure concentration, type and shape of MPs and organismal susceptibility. Effects were low ranging from MPs affecting growth or survival, feeding behavior and energy reserve of soil animals while high effects including death have not been reported. There is a need for studies for MPs in the presence of chemical containment on soil animals [1]. However, as pointed by van Gestel and Selonen, studies focusing on a full dose-response be conducted to address the precise toxicity effects of MPs on organisms is required and if such study adopted a co-exposure of MPs and chemical contaminants treatment testing, the experimental design should allow some kind of comparison between single and combined toxicities $[65,75]$.

\section{Human}

Currently, the toxicity of MPs to humans is still speculative as there are no studies yet to confirm the toxic effect. Previous reviews have explained in detail the potential effects of MPs to human from different environmental compartments $[1,4,5,16,17,39,50,76,77]$. These studies critically assessed the potential levels of exposure of particles, chemical and microbial hazards associated with MPs and also inform understanding of uptake, internalization, impacts and potential adverse human health outcomes of MPs. Overall, the plausible impact may include particle localization, microbial (biofilm with associated toxins) or chemical toxicity (with associated toxic chemicals).

Some recent in vitro studies have demonstrated the potential effects of MPs on human-derived cells [83-85]. These effects ranged from inflammation to DNA damage. Poma et al. analyzed the effects of PS nanoparticles (PS-NPs) in the Hs27 cell line at different time windows and polymer nanoparticle (PNP) concentrations [83]. The authors adopted the cytokinesis-block micronucleus (CBMN) assay to evaluate the geno- 
toxic effects of the PS and the after exposure to PNPs. The results obtained in the study showed damage in the DNA at different parameters of the CBMN test, which increased the formation of micronuclei and nuclear buds. The cellular responses of secondary PP MPs ( $~ 20 \mu \mathrm{m}$ and 25-200 $\mu \mathrm{m})$ were investigated in different conditions, such as size of normal cells, immune cells, blood cells, and murine immune cells by cytokine analysis, ROS assay, polarization assay and proliferation assay [84]. They found that PP particles showed low cytotoxicity effect in size and concentration of cells, however, a high concentration, small-sized, DMSO (dimethyl sulfoxide) method of PP particles stimulated the immune system and enhanced potential hypersensitivity to PP particles via an increase in the levels of cytokines and histamines in peripheral blood mononuclear cell (PBMCs), Raw 264.7 and HMC-1 cells. Wu et al. adopted a transcriptomic analytic method, and the molecular toxicity mechanisms of PS MPs was performed in vitro Caco-2 cell model [85]. The authors observed that PS-MPs decreased cell viability and it is dose-dependent while the responsible genes and involved pathways that might make contribution to PS-MBs-induced toxicity to Caco-2 cells were identified with Illumina RNA sequences. These pathways are involved in modulating cell inflammatory and proliferation. These studies defined the toxicity of small-sized plastic particles to humanderived cell and the resulting damage to DNA and inflammatory diseases. Further, providing a new insight into the understanding of the toxicity effects of MPs induced intestinal inflammatory diseases. However, further studies are needed to clarify the internalization process of MPs.

\section{CONCLUSION, RECOMMENDATION AND KNOWLEDGE GAPS}

Currently MPs are a threat to ecosystems. Studies on exposure akin toxicity in tandem with toxic chemical is very important to understanding MPs dynamics and developing a mitigation strategy. Humans are perhaps the most exposed organism mainly because they are at the top of the food chain. Exposure and toxicology effect to marine and freshwater organisms are classified based on exposure dosage as either high involving decreased reproductive output, damages to organ and death, or low - involving changes in behavior with time. Although toxicity studies regarding humans are still ongoing as per reports, plants and animals are still scantly studied. It is recommended that if a study adopted a co-exposure of MPs and chemical contaminants treatment testing, the experimental design should allow some kind of comparison between single and combined toxicities [65] because it is still difficult to compare these studies. This study, therefore, identified the following knowledge gaps that need to be filled:

- Few plants have only been studied for MPs exposure and effects on vegetative and reproductive growth. Meanwhile, there are more than 200,000 plant species, so it is clear that there is a need for more studies on more different plant species to better understand their response to MPs exposure.

- There is a need for study to determine if plants can accumulate toxic chemicals and MPs together from the soil. Also determining if the combined exposure effect on plants is synergistic, antagonistic or additive. This is a basis for precise risk assessment.

- As pointed by van Gestel and Selonen, studies focusing on a full dose-response be conducted to address the precise toxicity effects of MPs on organisms is required [75].

- There is a clear need for more scientific studies on the effects of MPs on human health.

\section{CONFLICTS OF INTEREST}

The authors declare no conflict of interest.

\section{REFERENCES}

1. Verla AW, Enyoh CE, Verla EN, Nwarnorh KO. Microplastic-Toxic Chemical Interaction: a Review Study on Quantified Levels, Mechanism and Implications. SN Appl Sci 2019;1:1400.

2. Rochman C M, Browne MA, Halpern BS, Hentschel BT, Hoh E et al. Policy: Classify plastic waste as hazardous. Nature 2013;494(7436): 169-171.

3. Enyoh CE, Verla AW, Verla EN. Uptake of microplastics by plant: a reason to worry or to be happy? World Scientific News 2019;131:256267.

4. Enyoh CE, Verla AW, Verla EN, Ibe FC, Amaobi CE. Airborne microplastics: a review study on method for analysis, occurrence, movement and risks. Environ Monitor Assess 2019;191(668):1-11.

5. Enyoh CE, Verla AW, Verla EN, Ihenetu SC. Macrodebris and microplastics pollution in Nigeria: first report on abundance, distribution and composition. Environ Anal Heal Toxicol 2019;34(4):1-15.

6. Enyoh CE, Verla AW. We are breathing Plastic; don't just look down, look up. Presented at the 3rd IMSU World Environment Day International Conference. 2019. [Cited Dec 12, 2019] Available from: https:// 10.13140/RG.2.2.21027.91680

7. Wang J, Liu X, Li Y, Powell T, Wang X, Wang G et al. Microplastics as contaminants in the soil environment: A mini-review. Sci Total Environ 2019;691:848-857.

8. Yang D, Shi H, Li L, Li J, Jabeen K, Kolandhasamy P. Microplastic pollution in table salts from China. Environ Sci Technol 2015;49(22): 13622-13627.

9. Lwanga EH, Gertsen H, Gooren H, Peters P, Salánki T, Ploeg M et al. Microplastics in the terrestrial ecosystem: implications for Lumbricus terrestris (Oligochaeta, Lumbricidae). Environ Sci Technol 2016;50(5): 
2685-2691.

10. Anbumani S, Kakkar P. Ecotoxicological effects of microplastics on biota: a review. Environ Sci Poll Res 2018;25(15):14373-14396.

11. Zhu L, Bai H, Chen B, Sun X, Qu K, Xia B. Microplastic pollution in North Yellow Sea, China: Observations on occurrence, distribution and identification. Sci Total Environ 2018;636:20-29.

12. Rodríguez-Seijo A, da Costa JP, Rocha-Santos T, Duarte AC, Pereira R. Oxidative stress, energy metabolism and molecular responses of earthworms (Eisenia fetida) exposed to low-density polyethylene microplastics. Environ Sci Pollut Res 2018;25(33):33599-33610.

13. Qi Y, Yang X, Pelaez AM, Lwanga EH, Beriot N, Gertsen H et al., Macro-and micro-plastics in soil-plant system: effects of plastic mulch film residues on wheat (Triticum aestivum) growth. Sci Total Environ 2018;645:1048-1056.

14. Galloway TS, Cole M, Lewis C. Interactions of microplastic debris throughout the marine ecosystem. Nat Ecol Evol 2017;1(5):1-8.

15. Verla AW, Enyoh CE, Verla EN. Microplastics, an emerging concern: a review of analytical techniques for detecting and quantifying microplastics. Anal Methods Environ Chem J 2019;2(2):13-30.

16. Wright SL, Kelly FJ. Plastic and human health: a micro issue? Environ Sci Technol 2019;51(12):6634-6647.

17. Gasperi J Wright SL, Dris R, France C, Corinne M, Mohamed G et al. Microplastics in air: are we breathing it in? Curr Opin. Environ Sci Health 2018;1:1-5.

18. Zhu F, Changyin Z, Chao W, Cheng G. Occurrence and ecological impacts of microplastics in soil systems: a review. Bull Environ Contam Toxicol 2019;102(6):741-749.

19. Zimmermann, Y-S, Schäffer A, Hugi C, Fent K, Corvini PF-X, Lenz M. Organic photovoltaics: Potential fate and effects in the environment. Environ Int 2012;49:128-140.

20. McHale G, Newton MI, Shirtcliffe NJ. Water-repellent soil and its relationship to granularity, surface roughness and hydrophobicity: a materials science view. Eur J Soil Sci 2005;56(4):445-452.

21. Saxton KE, Rawls WJ. Soil water characteristic estimates by texture and organic matter for hydrologic solutions. Soil Sci Soc Am J 2006; 70(5):1569-1578.

22. Verla AW, Verla EN, Chigbo MA, Kelechi CL, Ngozi OS, Enyoh CE. Biomonitoring of heavy metals in blood and urine of African children from Owerri metropolis, Eastern Nigeria. J Chem H Risks 2019;9(1): 11-26.

23. Rochman CM, Tahir A, Williams SL, Baxa DV, Lam R, Miller JT et al. Anthropogenic debris in seafood: plastic debris and fibers from textiles in fish and bivalves sold for human consumption. Sci Rep 2015; $5: 14340$.

24. Cunningham E M, Sigwart JD. Environmentally accurate microplastic levels and their absence from exposure studies. Integr Comp Biol, 2019;59(6):1485-1496.

25. Burns EE, Boxall AB. Microplastics in the aquatic environment: evidence for or against adverse impacts and major knowledge gaps. Environ Toxicol Chem 2018;37(11):2776-2796.

26. Lusher AL, Hernandez-Milian G, O'Brien J, Berrow S, O'Connor I, Officer R. Microplastic and macroplastic ingestion by a deep diving, oceanic cetacean: the True's beaked whale Mesoplodon mirus. Environ Pollut 2015;199:185-191.

27. Mateos-Cárdenas A, Scott DT, Seitmaganbetova G, van Pelt FNAM,
O'Halloran J, Jansen MAK. Polyethylene microplastics adhere to Lemna minor (L.), yet have no effects on plant growth or feeding by Gammarus duebeni (Lillj.). Sci Total Environ 2019;689:413-421.

28. Bandmann V, Müller JD, Köhler T, Homann U. Uptake of fluorescent nano beads into BY2-cells involves clathrindependent and clathrinindependent endocytosis. FEBS Lett 2012;586:3626-3632.

29. Li L, Zhou Q, Yin N, Tu C, Luo Y. Uptake and accumulation of microplastics in an edible plant. Chin Sci Bull 2019;64:928-934.

30. Loeb GI, Neihof RA. Marine conditioning films. In: Applied chemistry at protein interfaces, Am Chem Soc 1975;145:319-335.

31. Ocean Plastics Lab, Exhibition: science vs. plastic waste. 2018, Brussels, Belgium.

32. United Nations Environmental Programme (UNEP). Marine debris: understanding, preventing and mitigating the significant adverse impacts on marine and coastal biodiversity. Secretariat of the Convention on Biological Diversity. 2016; Technical series 83:1-78.

33. Lusher A, Hollman P, Mendoza-Hill J. Microplastics in fisheries and aquaculture: status of knowledge on their occurrence and implications for aquatic organisms and food safety. FAO fisheries and aquaculture technical paper, 2017;615.

34. O'Connor JD, Mahon AM, Ramsperger AFRM, Trotter B, RedondoHasselerharm PE, Koelmans AA et al. Microplastics in freshwater biota: a critical review of isolation, characterization, and assessment methods. Glob Challenges 2019;1800118.

35. Liebezeit G, Liebezeit E. Non-pollen particulates in honey and sugar. Food Add Contam Part A 2013;30:2136-2140.

36. Liebezeit G, Liebezeit E. Synthetic particles as contaminants in German beers. Food Add Contam Part A Chem Anal Control Expo Risk Assess 2014:31(9);1574-1578.

37. Karami A, Golieskardi A, Ho YB, Larat V, Salamatinia, B. Microplastics in eviscerated flesh and excised organs of dried fish. Sci Rep, 2017; $7(1): 1-9$.

38. Iñiguez ME, Conesa JA, Fullana A. Microplastics in Spanish table salt. Sci Rep 2017;7(1):1-7.

39. Revel M, Amélie C, Catherine M. Micro(nano)plastics: a threat to human health? Curr Opin Environ Sci Health 2018;1:17-23.

40. World Health Organization (WHO). Information sheet: Microplastics in drinking-water. 2019 [cited Dec 12, 2019] Available from: https:// www.who.int/water_sanitation_health/water-quality/guidelines/microplastics-in-dw-information-sheet/en/

41. Catarino AI, Valeria M, William GS, Richard CT, Theodore BH. Low levels of microplastics (MP) in wild mussels indicate that MP ingestion by humans is minimal compared to exposure via household fibres fallout during a meal. Environ Pollut 2018;237:675-684.

42. United Nations Environment Programme (UNEP). Plastic Cosmetics: Are We Polluting the Environment Through our Personal Care? [cited Dec 12, 2019] Available from: http://unep.org/gpa/ documents/publications/PlasticinCosmetics2015Factsheet.pdf.

43. Anderson AG, Grose J, Pahl S, Thompson RC, Wyles KJ. Microplastics in personal care products: Exploring perceptions of environmentalists, beauticians and students. Mar Pollut Bull 2019;113(1-2):454-460.

44. Kau, B. For the first time, study confirms presence of microplastics in Indian cosmetics. 2018 [cited Dec 13, 2019]. https://www.downtoearth.org.in/news/environment/for-the-first-time-study-confirmspresence-of-microplastics-in-indian-cosmetics-60365 
45. Leslie HA. Review of microplastics in cosmetics. IVM Institute for Environmental Studies 2014;476:1-33.

46. Desforges JPW, Galbraith M, Ross PS. Ingestion of microplastics by zooplankton in the northeast Pacific Ocean. Arch Environ Contam Toxicol 2015;69:320-330.

47. Sun X, Li Q, Zhu M, Liang J, Zheng S, Zhao Y. Ingestion of microplastics by natural zooplankton groups in the northern South China Sea. Mar Pollut Bull 2017;115:217-224.

48. Van Cauwenberghe L, Claessens M, Vandegehuchte MB, Janssen CR. Microplastics are taken up by mussels (Mytilus edulis) and lugworms (Arenicola marina) living in natural habitats. Environ Poll 2015;199: 10-17.

49. Güven O, GökdaK, Jovanovi B, Kõdeys AE. Microplastic litter composition of the Turkish territorial waters of the Mediterranean Sea, and its occurrence in the gastrointestinal tract offish. Environ Poll 2017; 223:286-294.

50. Carbery M, Wayne AO, Thavamani P. Trophic transfer of microplastics and mixed contaminants in the marine food web and implications for human health. Environ Int 2018;115:400-409.

51. Allen S, Deonie A, Vernon RP, Gaël LR, Pilar DJ, Anaëlle S et al. Atmospheric transport and deposition of microplastics in a remote mountain catchment. Nat Geosci 2019;12:339-344.

52. Dris R, Gasperi J, Saad M, Mirande C, Tassin B. Synthetic fibers in atmospheric fallout: a source of microplastics in the environment? Mar Pollut Bull 2016;104:290-293.

53. Flament F, Francois G, Qiu H, Ye C, Hanaya T, Batisse D et al. Facial skin pores: a multiethnic study. Clin Cosmet Investig Dermatol 2015; 8:85-93.

54. World Health Organization (WHO). Determination of airborne fibre number concentrations: a recommended method, by phasecontrast optical microscopy (membrane filter method). 1997.

55. Vianello A, Rasmus LJ, Li L, Jes V. Simulating human exposure to indoor airborne microplastics using a breathing thermal manikin. Sci Rep 2019;9(1):1-11.

56. Boots B, Russell CW, Green DS. Effects of microplastics in soil ecosystems: above and below ground. Environ Sci Technol. 2019;53(19): 11496-11506.

57. Verla AW, Enyoh CE, Isiuku BO, Verla EN, Enyoh EC. Effect of macroand micro- plastics in soil on growth of juvenile lime tree (Citrus aurantium). Imo State University, Nigeria; 2020

58. Kalcíkova G, Gotvajn AZ, Kladnik A, Jemec A. Impact of polyethylene microbeads on the floating freshwater plant duckweed Lemna minor. Environ Pollut 2017;230:1108-1115.

59. Batel A, Linti F, Scherer M, Erdinger L, Braunbeck, T. Transfer of benzo[a] pyrene from microplastics to Artemia nauplii and further to zebrafish via a trophic food web experiment: CYP1A induction and visual tracking of persistent organic pollutants. Environ Toxicol Chem 2016;35:1656-1666.

60. Brandts I, Teles M, Gonçalves AP, Barreto A, Franco-Martinez L, Tvarijonaviciute A et al. Effects of nanoplastics on Mytilus galloprovincialis after individual and combined exposure with carbamazepine. Sci Total Environ 2018;643:775-784.

61. Browne MA, Niven SJ, Galloway TS, Rowland SJ, Thompson RC. Microplastic moves pollutants and additives to worms, reducing functions linked to health and biodiversity. Curr Biol 2013;23:2388-2392.
62. O'Donovan S, Mestre NC, Abel S, Fonseca TG, Carteny CC, Cormier B, et al, Ecotoxicological Effects of chemical contaminants adsorbed to microplastics in the clam Scrobicularia plana. Front Marine Sci 2018; 5:143.

63. Verla AW, Enyoh CE, Verla EN. The importance of microplastics pollution studies in water and soil of Nigeria ecosystems. Anal Methods Environ Chem J 2019;2(3):89-96.

64. Zhang Q, Qu Q, Lu T, Ke M, Zhu Y, Zhang M et al. The combined toxicity effect of nanoplastics and glyphosate on Microcystis aeruginosa growth. Environ Pollut 2018;243:1106-1112.

65. Tourinho PS, Kočí V, Loureiro S, van Gestel CAM. Partitioning of chemical contaminants to microplastics: Sorption mechanisms, environmental distribution and effects on toxicity and bioaccumulation. Environ Pollut 2019;252B:1246-1256.

66. Rehse S, Kloas W, Zarfl C Microplastics reduce short-term effects of environmental contaminants. Part I: effects of bisphenol A on freshwater zooplankton are lower in presence of polyamide particles. Int J Environ Res Public Health 2018;15(2):280.

67. Horton AA, Vijver MG, Lahive E, Spurgeon DJ, Svendsen C, Heutink R et al. Acute toxicity of organic pesticides to Daphnia magna is unchanged by co-exposure to polystyrene microplastics. Ecotoxicol Environ Saf 2018;166:26-34.

68. Frydkjær CK, Iversen N, Roslev P. Ingestion and egestion of microplastics by the cladoceran Daphnia magna: effects of regular and irregular shaped plastic and sorbed phenanthrene. Bull Environ Contam Toxicol 2017;99:655-661.

69. Fonte E, Ferreira P, Guilhermino L. Temperature rise and microplastics interact with the toxicity of the antibiotic cefalexin to juveniles of the common goby (Pomatoschistus microps): post-exposure predatory behaviour, acetylcholinesterase activity and lipid peroxidation. Aquat Toxicol 2016;180:173-185.

70. Davarpanah E, Guilhermino L. Single and combined effects of microplastics and copper on the population growth of the marine microalgae Tetraselmis chuii. Estuar Coast Shelf Sci. 2015;167:269-275.

71. Sleight VA, Bakir A, Thompson RC, Henry TB, Assessment of microplastic sorbed contaminant bioavailability through analysis of biomarker gene expression in larval zebrafish. Mar Pollut Bull 2017;116: 291-297.

72. Ma Y, Huang A, Cao S, Sun F, Wang L, Guo H et al. Effects of nanoplastics and microplastics on toxicity, bioaccumulation, and environmental fate of phenanthrene in fresh water. Environ Pollut 2016;219:166173.

73. Kim D, Chae Y, An YJ. Mixture toxicity of nickel and microplastics with different functional groups on Daphnia magna. Environ Sci Technol 2017;51:12852-12858.

74. Critchell K, Hoogenboom MO. Effects of microplastic exposure on the body condition and behaviour of planktivorous reef fish (Acanthochromis polyacanthus). PLoS ONE 2018;13(3):e0193308.

75. van Gestel CAM, Selonen S. Ecotoxicological effects of microplastics in soil: comments on the paper by Zhu et al. 'Exposure of soil collembolans to microplastics perturbs their gut microbiota and alters their isotopic composition.' Soil Biology \& Biochemistry 2018;116:302-310. Soil Biol Biochem 2018;124:116-117.

76. Smith M, David CL, Chelsea MR, Roni AN. Microplastics in seafood and the implications for human health. Curr Environ Health Rep 
2018;5(3):375-386.

77. Prata JC. Airborne microplastics: Consequences to human health? Environ Pollut 2018;234:115-126.

78. Mintenig SM, Löder MGJ, Primpke S, Gerdts G. Low numbers of microplastics detected in drinking water from ground water sources. Sci. Total Environ 2019;648:631-635.

79. Capozzi F, Carotenuto R, Giordano S, Spagnuolo V. Evidence on the effectiveness of mosses for biomonitoring of microplastics in fresh water environment. Chemosphere 2018;205:1-7.

80. Bosker T, Lotte JB, Nadja RB, Paul B, Martina GV. Microplastics accumulate on pores in seed capsule and delay germination and root growth of the terrestrial vascular plant Lepidium sativum. Chemosphere 2019;226:774-781.

81. van Weert S, Redondo-Hasselerharm PE, Diepens NJ, Koelmans AA.
Effects of nanoplastics and microplastics on the growth of sedimentrooted macrophytes. Sci Total Environ 2019;654:1040-1047.

82. Xiaofeng J, Hao C, Yuanchen L, Ziqi Y, Mei L, Georan K. Ecotoxicity and genotoxicity of polystyrene microplastics on higher plant Vicia faba. Environ Pollut 2019;250:831-838.

83. Poma A, Vecchiotti G, Colafarina S, Zarivi O, Aloisi M, Arrizza L et al., In vitro genotoxicity of polystyrene nanoparticles on the human fibroblast Hs27 cell line. Nanomaterials 2019;9(9):1299.

84. Hwang J, Choi D, Han S, Choi J, Hong J. An assessment of the toxicity of polypropylene microplastics in human derived cells. Sci Total Environ 2019;684:657-669.

85. Wu S, Wu M, Tian D, Qiu L, Li T. Effects of polystyrene microbeads on cytotoxicity and transcriptomic profiles in human Caco-2 cells. Environ Toxicol 2019;1-12. 